\title{
PERKAWINAN POLIGAMI DI DESA SERENANG KECAMATAN PUJUT KABUPATEN LOMBOK TENGAH
}

\author{
Dian Eka Mayasari Sri Wahyuni', Wahab² \\ ${ }^{1,2}$ Pendidikan Sejarah, Universitas Muhammadiyah Mataram, dianekamayasari30s@gmail.com \\ ${ }^{2}$ Pendidikan Sejarah, Universitas Muhammadiyah Mataram
}

INFO ARTIKEL

RiwayatArtikel:

Diterima:07-04-2017

Disetujui:08-05-2017

\section{Kata Kunci:}

1. Sebab - Akibat

2. Perkawinan

3. Poligami

\begin{abstract}
ABSTRAK
Tujuan penelitian ini adalah untuk mengetahui faktor-faktor sebab dan akibat perkawinan poligami di Desa Serenang Kecamatan Pujut Kabupaten Lombok Tengah. Pendekatan yang digunakan adalah pendekatan kualitatif. Metode pengumpulan data meliputi observasi, wawancara, dan dokumentasi. Metode analisis data yang digunakan adalah metode deskriptif kualitatif. Hasil penelitian yaitu penyebab terjadinya perkawinan poligami oleh para suami di Desa Serenang Kecamatan Pujut yaitu antara lain : a) kebutuhan seksual, b) ingin mendapatkan keturunan (istri mandul), c) adanya suatu kebanggaan, d) faktor pendidikan, e) istri kurang merawat diri, dan akibat perkawinan poligami oleh para suami di Desa Serenang Kecamatan Pujut yaitu antara lain : a) psikologis, b) pendidikan anak, c) moral, d) hak-hak suami istri, dan e) akibat filsafat
\end{abstract}

\begin{abstract}
The purpose of this research is to know the factors of cause and effect of polygamy marriage in Serenang Village, Pujut Sub-district, Central Lombok Regency. The approach used is qualitative approach. Methods of data collection include observation, interviews, and documentation. Data analysis method used is qualitative descriptive method. The result of the research is the cause of polygamy marriage by husbands in Serenang Village Pujut Sub-district, among others: a) sexual needs, b) want to get offspring (barren wife), c) existence of pride, d) education factor, e) wife less caring self, and the consequences of polygamy marriage by husbands in Serenang Village Pujut Sub-district, among others: a) psychological, b) children's education, c) moral, d) marital rights, and e) due to philosophy
\end{abstract}

\section{A. LATAR BELAKANG}

Perkembangan peradaban merupakan realita kehidupan manusia mulai era prasejarah sampai era terkini dan seterusnya. Salah satu peristiwa yang sangat penting dalam perjalanan hidup seseorang di tengah masyarakat yang memiliki peradaban adalah dilangsungkannya perkawinan. Perkawinan yang dilaksanakan ini dilatar belakangi oleh berbagai tujuan yang akan membawa akibat terhadap kehidupan manusia baik terhadap dirinya, orang lain maupun terhadap harta kekayaan.

Perkawinan merupakan salah satu perbuatan yang berhubungan dengan kerohanian seseorang. Perkawinan menurut konsep hukum Islam adalah suatu ibadah yang sunat muakkad yang berlandaskan Al-Quran dan Hadits Nabi. Di samping perbuatan pribadi yang berhubungan dengan orang lain juga sebagai perbuatan keagamaan serta perbuatan hokum yang dilakukan antara laki-laki dengan perempuan.
Musfir Aj-Jahrani (2001:16) mengemukakan perkawinan merupakan hubungan cinta kasih sayang dan kesenangan sarana bagi terciptanya kerukunan hati, serta sebagai pariasi bagi suami istri dari bahaya kekejian. Dengan perkawinan lahirlah generasi yang memperkaya umat, memperkokoh kekuatannya, serta meningkatkan perekonomian. Oleh karena itu, dengan adanya perkawinan akan terjadi sikap tolong-menolong antara laki-laki dan perempuan dalam kepentingan dan tuntutan kehidupan.

Dalam perkawinan hanya dikenal prinsip monogomi, seorang suami dibenarkan mempunyai seorang istri tetapi karena keadaan masyarakat yang pluralistik yaitu suatu kenyataan dalam masyarakat kita memeluk agama yang berlainan maka poligami diperbolehkan jika syarat-syarat tertentu dipenuhi. Poligami adalah perkawinan yang dilakukan oleh seorang laki-laki terhadap dua orang perempuan atau lebih dalam waktu yang bersamaan (beristri lebih dari 
satu).

Poligami telah diatur dalam Undang-undang Perkawinan. Namun terkadang suami menikah lagi tanpa memenuhi syarat-syarat yang telah ditentukan yaitu adanya persetujuan istri, adanya kepastian bahwa suami mampu menjamin keperluan hidup istri-istri dan anak-anaknya, dan yang paling utama syarat untuk berpoligami adalah suami dapat berlaku adil. Petunjuk Undang- undang Perkawinan menunjukkan bahwa berpoligami mempunyai persyaratan yang cukup ketat. Ketatnya persyaratan menyebabkan sering terjadinya pelanggaran dari petunjuk yuridis itu sehingga masyarakat lebih memilih melakukan perkawinan poligami tanpa melalui izin pengadilan, dengan syarat sudah memenuhi rukun dan syarat sahnya perkawinan.

Sehubungan dengan masalah perkawinan poligami tersebut di atas, praktek perkawinan poligami juga marak terjadi di masyarakat di Desa Serenang Kecamatan Pujut Lombok Tengah. Salah satu satu faktor yang sangat urgen.

untuk diketahui dalam rangka mengungkap seluk beluk poligami di kalangan masyarakat muslim Sasak di Desa Serenang Kecamatan Pujut Lombok Tengah adalah motivasi kaum laki-laki dan perempuan melakukan poligami. Terjadinya poligami di kalangan masyarakat disebabkan faktor antara satu dengan yang lainnya berbeda. Faktor-faktor tersebut memang secara akumulatif pada setiap kasus poligami, melainkan setiap kasus poligami adakalanya disebabkan oleh satu faktor dan adakalanya disebabkan oleh dua faktor atau lebih. Faktor-faktor tersebut antara lain adalah ekonomi, sosial, budaya, pendidikan, dan biologis.

Faktor ekonomi yang dimaksud adalah seorang laki-laki melakukan perkawinan poligami karena mampu memberikan nafkah lahir batin kepada istri- istrinya. Faktor sosial adalah seorang laki-laki melakukan perkawinan poligami karena pengaruh lingkungan sosial atau karena lingkungan masyarakat ikut memberikan kontribusi bagi terjadinya perkawinan poligami. Faktor budaya yang dimaksud adalah seorang laki-laki melakukan perkawinan poligami karena keturunan atau semacam image bahwa perkawinan poligami merupakan bagian dari tradisi turun temurun. Faktor pendidikan yang dimaksud adalah seorang laki- laki melakukan perkawinan poligami karena ketidaktahuan tentang tujuan dan maksud serta konsekuensi dari perkawinan poligami. Faktor biologis yang dimaksud adalah seorang laki-laki melakukan perkawinan poligami karena ingin memuaskan nafsu biologis pada dirinya.

\section{B. METODE PENELITIAN}

Pendekatan yang digunakan dalam penelitian ini adalah pendekatan kualitatif. Adapun langkah-langkah dalam penelitian ini: 1) Melakukan survei di lapangan ditujukkan kepada masyarakat yang bermukim Desa Serenang Kecamatan Pujut Kabupaten Lombok. 2) Menentukan cara pengembangan hasil studi awal dengan menerapkan konsep-konsep atau teori-teori yang berkaitan dengan fokus penelitian yang dilaksanakan.

3) Pengembangan semua fokus sampai kriteria yang sudah ditentukan akan dicapai dalam penelitian ini. Lokasi penelitian diDesa Serenang Kecamatan Pujut Kabupaten Lombok Tengah. Letak lokasi penelitian ini berada di kawasan pedalaman Lombok Selatan berjarak sekitar 30 km di sebelah selatan Kota Kabupaten Lombok Tengah. Metode pengumpulan data yang digunakan dalam penelitian ini adalah metode observasi, metode wawancara, dan metode dokumentasi. Metode analisis data yang digunakan adalah metode deskriptif kualitatif.

\section{HASIL DAN PEMBAHASAN}

\section{Faktor Penyebab Poligami} a) Kebutuhan Seksual

Motivasi yang digunakan oleh laki-laki dalam hal berpoligami hanyalah untuk memberi kepuasan seksual dari dirinya. Kemungkinan terjadinya istri bersikap dingin terhadapnya, kurang bergairah dalam permainan seks. Dalam bermain seks, istri pasif, tidak mau memberi dan menerima, kurang aktif, bersifat monoton. Sedangkan suami dengan sering menonton film seks dan buku-buku seks mempelajari berbagai macam cara bersenggama yang dilakukan bintang film blue, atau sebagaimana diceritakan dalam buku seksual, buku pendidikan maupun buku porno yang penuh gambar permainan seks dan senggama, menginginkan model yang bervariasi. 
Sementara istrinya tidak mampu menjalankan apa yang diinginkannya, atau memang tidak mau karena malu dan kurang sesuai dengan ajaran agama maupun kesopanan adat yang dipegang oleh istri enggan melakukan adegan panas, akibatnya suami kurang puas dan berusaha mencari istri lagi. Fegiditas istri dan tipenya demikian atau memungkinkan dari suami karena terlalu kasar emosional pada malam pertama sehingga istri merasa kesakitan setiap permainan seks pada hari-hari berikutnya

Seorang suami hypersex yang mempunyai daya lebih dalam seks yang selalu tidak puas dalam permainan seks dan selalu kurang. Setelah bersenggama alat vitalnya bangkit lagi, selalu ingin bersenggama, sedangkan istri tidak kuat lagi untuk melayaninya, sehingga berusaha bermain seks dengan perempuan lain, akhirnya dia berpoligami, untungnya dia tidak melacur, zina dan sebagainya yang dilarang oleh agama dan melanggar norma kesusilaan.

\section{b) Istri Pertama Mandul}

Seorang suami berusaha untuk mendapatkan keturunan, laki-laki yang berpoligami karena istri tidak dapat memberi keturunan/anak atau istri mandul dna sudah berkali-kali berusaha untuk mengatasi penyakitnya agar bisa meneruskan keturunan dan akan tetapi usahanya belum juga berhasil, bahkan suami juga ikut membantu mengethaui sebabnya. Dalam hal ini sangat tidak adil jika suamitidak diijinkan untuk menikah lagi. Sedangkan untuk mengadopsi anak seorang suami bisa menerima tetap ada kalanya suami belum puas apabila belum mempunyai anak sendiri. Sehingga suami melakukan perkawinan poligami dengan harapan agar madunya nanti dapat memberikan anak atau keturunan sebagai penerusnya. Jika tidak mempunyai keturunan akan terasa hampa dan hambar dalam kehidupan keluarga. Tidak ada penghibur dan yang terpenting tujuannya agar dimasa tua kelak meraka ada anak yang merawat, jadi masa tua tidak terlantar karena ada anak yang akan merawatnya dengan tulus dan penuh kasih sayang.

\section{c) Faktor Pendidikan}

Masyarakat Desa Serenang kebanyakan yang berpoligami dari kalangan generasi tua, dan mereka yang kurnag berpendidikan. Hal tersebut karena mereka melihat poligamiu dari segi kebolehannya, tetapi belum bisa memikirkan tentang dampaknya terhadap pendidikan anak- anaknya. Sedangkan mereka yang berpendidikan akan berfikir panjang untuk melakukan dan menerima poligami

\section{d) Istri Kurang Merawat Dirinya}

Pada umumnya wanita jika sudah mempunyai suami dan anak, kurang bisa merawat dirinya dalam segi kebersihannya, cara berpakaian dan sebagainya. Dengan demikian suaminya akan merasa bosan melihatnya sehingga mereka para suami ingin mencari istri baru lagi

\section{e) Adanya Suatu Kebanggaan}

Poligami yang dilakukan bagi seorang suami merupakan suatu kebanggaan tersendiri. Untuk seorang suami yang beristrikan lebih dari seornag akan merasakan dirinya lebih jantan dan hebat. Dismaping itu, dalam pandangan masyarakat Desa Serenang, bahawa semakin bertambah istrinya semakin dipandang bahwa dia semakin banyak tingkat kekayaannya dalam kehidupannya di masyarakat. Dengan cara beristri lebih dari satu (berpoligami) kadang-kadang dia memamerkan harta kekayaannya Disamping itu ada rasa seni tersendiri karena setiap bergantian tempat dari istri satu ke tempat istri yang lain selalu merasakan nikmatnya, itu sudah merupakan satu kebanggaan tersendiri bagi seorang suami berpoligami

\section{f) Pengaruh Lingkungan}

Mereka yang melakukan poligami sebagian besar ikut-ikutan untuk berpoligami di tengah-tengah kenyataan lingkungan seperti ini laki-laki yang mempunyai seorang istri (monogami) menjadi ejekan laki-laki yang memiliki istri lebih dari seorang yang monogami dikatakan tidak jantan sehingga ejekan-ejekan tersebut akan mendorong para suami untuk mencari istri lagi. Mereka ingin memberikan bahwa mereka juga bisa beristri dari seorang seperti mereka, bisa lebih jantan walau kedengarannya "egois" cuma karena ingin pembuktian terhadap ejekan, perasaan wanita atau istrinya disakiti dengan melakukan poligami.

\section{g) Suami Merasa Bosan Hanya Dilayani Oleh Seorang Istri}

Suami yang telah merasa bisosan terhadap istrinya berakibat tidak kerasan tinggal di rumah, 
kemudian sering keluar mencari pasangan hidup yang baru menurut mereka yang berpoligami bahwa hidup dengan seorang istri akan menyebabkan mereka kurang giat untuk bekerja mencari nafkah Apabila suami beristri lebih dari seorang mereka akan bekerja giat dan beban menjadi ringan karena banyak teman untuk bisa diajak bekerjasama memikul beban dan setiap dua atau tiga hari terjadei pergantian suasana sehingga hidup tidak monoton dan membosankan.

\section{h) Tugas Terlalu Jauh}

Seorang istri yang pergi keluar negeri untuk menjadi TKW (Tenaga Kerja Wanita) dalam waktu yang lama sehingga menyebabkan mereka jarang berteamu untuk melepaskan keinginan berkaitan dengan masalah ranjang. Suami merasa kesepian ditinggal selain itu tidak ada yang mengurus rumah tangga dan karena suami juga bekerja jadi anak- anaknya juga terlantar karena tidak ada yang mengurus Dalam keadaan seperti ini suami berkeinginan untuk mencari istri baru selain itu seornag suami yang merasa masih normal, ingin mencari pasangan hidup agar bisa melampiaskan keinginan untuk berhubungan seks dari pada berbuat zina di luar yang sangat tercela dan dibenti Allah SWT. Untuk menghindari terjadinya hal tersebut menjadi pendorong pelaksanaan poligami.

\section{i) Berbuat Baik Kepada Wanita yang Terlantar}

Penyebabnya karena wanita tersebut sudah lama menjanda dna terlantar dan tidak ada yang menopang biaya hidupnya sehari-hari. Dalam keadaan seperti ini poligami dianggap sebagai sesuatu yang makruf. Karena tujuannya melindungi wanita-wanita yang terhalang dari perkawinan

\section{j) Masa Subur Perempuan Terbatas}

Sebagian orang berpendapat bahwa faktor terbatasnya usia reproduktif perempuan, yakni masa menopuse adalah salah satu penyebab poligami. Dalam kasus ini seorang perempuan mencapai masa menopuse lebih dini. Hasrat suami untuk tetap bersama dengan istrinya yang pertama karena masih sayang dan dengan pertimbangan "anak" walaupun dengan mengawini istri kedua atau ketiga, tidak berarti harus mengurangi rasa sayang dan kebersamaan dengan istri pertama dan anak-anaknya. Disamping agar anak-anaknya tetap merasa senang, nyaman dan tentram dengan bersatunya bapak dan ibunya dalam keluarganya.

\section{k) Menstruasi dan Pasca Kelahiran}

Sebagai peneliti, pada faktor ini ada rasa kaget dan tidak percaya bahwa memang ada penyebab suami untuk berpoligami dengan alasan ini. Kenyataan ini terjadi juga di Desa Serenang. Poligami pada haid bulanan perempuan dan ketidaksanggupan untuk mengadakan hubungan seksual selama masa haid Kecakapannya selalu melahirkan dan pematangannya dalam segi seksual kehidupan dan kesibukannya dalam menyusui dan membesarkan anak-anaknya. Haid bulanan pada perempuan sebagaimana juga kelesuannya sesudah melahirkan, menempatkan pihak perempuan dan suaminya dalam posisi seksual yang berbeda dan menimbulkan situasi dimana suami cenderung untuk mencari perempuan lain atau berpoligami

\section{1) Faktor Agama dan Naluri Sosial Budaya Tertentu}

Perkawinan poligami merupakna Sunnah Rasul atau Nabi disamping itu masyarakat Desa Serenang mengetahui bahwa perbuatan zina sangat tercela dan sangat dibenci. Ada suami yang berpoligami bukan karena dorongan dan pertimbangan macam-macam, tanpa melihat istri cantik atau tidak, tanpa melihat calon istri keduanya atua tidak, keturunan ningrat atau tidak dan tanpa melihat pertimbangan plitik atau tujuan tertentu, semata-mata hanya karena pertimbangan gama, seperti orang muslim yang taat, poligami hanya melaksanakan Sunnah Rasul. Ada kalanya suami yang berpoligami untuk menalurikan atau menghidupkan budaya tertentu tetapi masih ada faktor lain juga dalam poligami yaitu berdasarkan cinta, kasih sayang

\section{m) Istri Melanggar Perjanjian}

Istri melanggar perjanjian dimaksud disini sebelum istri pergi jadi TKI ke Saudi Arabia telah berjanji kepada suami untuk pergi selama 2 tahun atau cukup menghabisi kontrak yang telah ditentukan oleh majikannya, namun dalam kurun waktu yang telah ditentukan dia pun belum pulang ke tanah air. Kondisi demikianlah yang menyebabkan suami tersebut menikah lagi.

\section{Faktor Akibat Poligami}

a) Akibat Psikologis 
Adanya permusuhan di antara istri-istri menyusahkan suasana kehidupan rumah tangga, menyebabkan suami sibuk memikirkan pertengkaran istri-istrinya saja, dan mencari solusi untuk mendamaikan mereka. Hal itu menjadikan kehidupan suami seperti neraka yang tidak dapat ditanggung panasnya. Keadaan istri-istrinya juga akan merupakan medan pertempuran yang tidak ada henti-hentinya, hal itu disebabkan oleh rasa cemburu.

\section{b) Akibat Terhadap Pendidikan Anak}

Pertengkaran istri-istrinya sering berakibat kepada anak-anak mereka. Jadi anak-anak saudara seayah itu bermusuhan dan saling membenci. Dalam hal ini anaklah yang banyak terganggu ketenangannya dan kebahagiaan hidup berumah tangga. Karena orang tua tidak memperhatikan pendidikan anak, disebabkan pikirannya yang tidak tenang dan sibuk dengan urusan-urusan istri-istri yang sering bertengkar. Akibatnya, pendidikan anak terbengkalai.

\section{c) Akibat Terhadap Moral}

Izin poligami adalah izin kehidupan penuh hawa nafsu, merupakan izin laki-laki untuk merubah diri dalam sosialisme. Moralitas menuntut bahwa seseorang harus mengurangi dan memerangi hawa nafsunya sampai kepada tingkat yang lebih rendah. Sementara, seseorang yang melakukan poligami merupakan orang yang tidak mampu menahan hawa nafsunya. Hal ini mengakibatkan moral mereka tidak sesuai dengan tuntunan agama.

\section{d) Akibat Terhadap Hak-hak Suami Istri}

Dengan akad nikah, masing-masing pasangan dari suami-istri terpaut satu sama lainnya dan menjadi bagian yang utuh. Hak untuk mendapatkan kepuasan, dan kepuasaan timbal balik. Hal ini berarti bahwa masingmasing berhak atas segala manfaat yang dating dari pihak lain. Akad yang dibuat suami dengan perempuan lain, dalam kenyataannya adalah suatu akad yang tidak berwenang. Apabila suami bermaksud untuk mengambil istri kedua, istri pertamalah yang memiliki kekuasaan untuk mengambil keputusan berkaitan dengan suaminya dalam hal pemberian persetujuan apabila suami berkeinginan untuk menikah lagi

e) Akibat Terhadap Filsafat
Hukum poligami bersifat konsisten dengan filsafah tentang persamaan hak laki-laki dan perempuan yang bertumpu kepada persamaan seluruh manusia, karena laki-laki dan perempuan adalah manusia yang memiliki hak yang sama. Kedua hak tersebut mempunyai beberapa pasang atau tidak seorang laki-laki bebas memilih beberapa orang. Sedang seorang perempuan tidak bebas mempunyai beberapa orang suami adalah suatu diskriminasi yang tidak adil dan secara tidak semestinya menguntungkan laki-laki.-laki.

\section{Faktor Internal dan Eksternal Poligami}

a) Faktor Internal Poligami

Faktor internal poligami dapat dikemukakan bahwa terdapat gejolak dalam pribadi laki-laki untuk berpoligami, seperti suami merasa memiliki hak untuk melakukan poligami, suami ingin menyalurkan nafsu seksualnya kepada perempuan lain, suami merasa ada kebanggaan tersendiri dalam dirinya jika memiliki istri lebih dari satu.

Faktor internal poligami ini dapat tumbuh dengan sendirinya jika dalam diri pribadi patra suami muncul dorongan yang kuat dari dalam dirinya untuk berpoligami tanpa dipengaruhi oleh faktor dari luar dirinya. Hal ini dapat berupa dorongan seksual yang tinggi, sehingga timbul keinginan untuk melampiaskan nafsu seksualnya kepada wanita lebih dari satu orang

\section{b) Faktor Eksternal Poligami}

Faktor eksternal poligami dapat dikemukakan bahwa suami mendapat pengaruh dari teman-teman yang sudah berpoligami, adanya perempuan yang dilihat membutuhkan perlindungan sehingga dia menikahinya, adanya kebiasaan masyarakat Sasak untuk berpoligami, adanya kemudahan melakukan poligami dengan menikah sirih tanpa izin Pengadilan Agama.

Faktor eksternal ini dapat disebabkan pula dengan adanya perniakahan antara masyarakat Suku Sasak dengan warga asing yang berdomisili sementara di kawasan Lombok Selatan. Pernikahan ini terjadi dengan mudah karena perempuan yang dinikahi mendapatkan biaya hidup yang layak. Biasanya jika perempuan Suku Sasak dinikahi oleh warga asing, maka mereka akan mendapatkan biaya hidup yang layak meskipun dalam pernikahan ini kedua belah pihak yaitu laki-laki dan 
perempuan hanya tinggal bersama pada waktu pihak laki-laki berada di Lombok. Sementara pihak laki-laki harus pergi meninggalkan Lombok jika waktu visanya telah berakhir.

Pelaksanaan pernikahan pun dapat dilakukan dengan mudah karena dilakukan penikahan sirih tanpa dicatat secara resmi di Pengadilan Agama. Para pelaku dan para wali pun memudahkan pelaksanaan pernikahan ini karena mereka berdalih menyelesaikan hukum agama untuk menghindari perbuatan yang melanggar agama

\section{SIMPULAN DAN SARAN}

\section{Simpulan}

Berdasarkan uraian pada pembahasan terdahulu dapat diambil kesimpulan sebagai berikut:

a) Faktor penyebab terjadinya perkawinan poligami oleh para suami di Desa Serenang Kecamatan Pujut yaitu antara lain : 1) Kebutuhan seksual, 2) Ingin mendapatkan keturunan (istri mandul), 3) Adanya suatu kebanggaan, 4) Faktor pendidikan, 5) Istri kurang merawat diri. Sementara faktor akibat perkawinan poligami di Desa Serenang Kecamatan Pujut yaitu antara lain : 1) psikologis, 2) pendidikan anak, 3) moral, 4) hak-hak suami istri, dan 5) akibat filsafat.

b) Faktor internal poligami dapat dikemukakan bahwa terdapat gejolak dalam pribadi laki-laki untuk berpoligami, seperti suami merasa memiliki hak untuk melakukan poligami, suami ingin menyalurkan nafsu seksualnya kepada perempuan lain, suami merasa ada kebanggaan tersendiri dalam dirinya jika memiliki istri lebih dari satu. Faktor eksternal internal poligami dapat dikemukakan bahwa suami mendapat pengaruh dari teman-teman yang sudah berpoligami, adanya perempuan yang membutuhkan perlindungan, adanya kebiasaan masyarakat Sasak untuk berpoligami, adanya kemudahan melakukan poligami dengan menikah sirih tanpa izin Pengadilan Agama.

\section{Saran}

a) Bagi Masyarakat

Jika melakukan berpoligami hendaknya benarbenar memahami makna dari poligami tersebut, jangan hanya melihat dibolehkannya berpoligami menurut hukum Islam tetapi harus benar-benar dipertimbangkan baik dari segi finansial maupun dari segi keadilannya yang lain.

b) Bagi Pemerintah

Masih diperlukan adanya pelaksanaan UU No. 1/1974 secara lebih tegas dan efektif lagi tentang poligami, denagn langkah peningkatan penyuluhan hukum yang intensif pada semua tingkat lapisan masyarakat yang sifatnya menanamkan rasa kesadaran hukum kepada seluruh lapisan masyarakat sebab kebanyakan dari masyarakat desa hanya mengetahui hukum agama dan kurang mengetahui hukum negara.

c) Bagi Peneliti Lainnya

Bagi penliti selanjutnya hendaknya melakukan penelitian lanjutan dengan lebih mendalam sehingga hasilnya bisa membuka mata masyarakat tentang segala akibat yang berkaitan dengan poligami.

\section{DAFTAR RUJUKAN}

Aj-Jahrani, Musfir. 2001. Poligami dari Berbagai Persepsi. Jakarta: Gema Insani Press.

Arikunto, Suharsimi. 2003. Prosedur Penelitian-Suatu Pendekatan Praktis. Jakarta: Rineka Cipta.

Arikunto, Suharsimi. 2006. Prosedur Penelitian-Suatu Pendekatan Praktis Edisi Revisi. Jakarta: Rineka Cipta.

As-Said. 2002. Perkawinan Poligami. Jakarta: Gema Insani Press. Departemen Agama RI. 2004. Terjemahan Al-Quran. Surabaya: Jayasakti.

Malik, Rusdi. 2003. Undang-undang Perkawinan. Jakarta: Universitas Trisakti Press.

Margono. 2004. Metodologi Penelitian Pendidikan. Jakarta: Rineka Cipta.

Moleong, Lexi J. 2006. Metodologi Penelitian Kualitatif. Bandung: Remaja Rosdakarya.

Mursalin, Supardi. 2007. Menolak Poligami Studi Tentang Undang-undang Perkawinan dan Hukum Islam. Yogyakarta: Pustaka Pelajar. Rasjid, Sulaiman. 2002. Fiqh Islam. Bandung: Sinar Algensindo.

Riyanto, Yatim. 2001. Metodologi Penelitian Pendidikan. Surabaya: SIC. Sugiyono. 2008. Metode Penelitian Penddikan. Bandung: Alfbeta.

Sukardi. 2008. Metodologi Penelitian Pendidikan Kompetensi dan Praktiknya. Jakarta: Bumi Aksara.

Yasin, M. Nur. 2008. Hukum Perkawinan Islam Sasak. Malang: Universitas Negeri Malang Press. 